\title{
ZONE FOR COLLECTING THE IONS OF A GIVEN MASS RANGE IN THE PLASMA FILTER OF MASSES
}

\author{
V.V. Katrechko, V.B. Yuferov, V.O. Ilichova, A.S. Svichkar, S.N. Khizhnyak \\ National Science Center "Kharkov Institute of Physics and Technology”, \\ Kharkiv, Ukraine \\ E-mail: v.yuferov@kipt.kharkov.ua
}

The trajectories of motion for atomic and molecular ions of a given mass range $(\mathrm{M}=232 \ldots 277)$ in the plasma mass filter, which is currently being developed, are calculated. The influence of the initial conditions (energy, angle, radius) on the ion trajectory to determine the dimensions of the collector for actinides, the so-called "pocket", is studied. It is shown that the variable component of the radial electric field, tuned to a frequency equal to half the ion cyclotron frequency for $\mathrm{M}=238$ allows target ions to enter the "pocket". An analysis of the calculations showed that there are limitations on energy, angle, and radius related to the initial conditions for the ion motion, that must be taken into account when creating the plasma source for the plasma mass filter.

PACS: $28.41 \mathrm{Kw}$

\section{INTRODUCTION}

An alternative method of spent nuclear fuel (SNF) and radioactive waste $(\mathrm{RW})$ reprocessing is plasma mass separation, which does not require the use of chemicals and reduces the risk of environmental pollution. The development of plasma methods is associated with the development of facilities with high productivity for plasma separation of SNF into nuclear fuel (NF) and fission products (FPs). A promising direction is the development of separators with plasma rotating in crossed ExH fields, a variety of which are plasma filters of masses [1-3].

At present, the concept of a model of plasma mass filter for irradiated oxide fuel [4] with a productivity of $15 \ldots 20$ tones per year of a non-radioactive model mixture, in particular SIMFUEL [5], is being developed.

Earlier [4, 6], the trajectories of molecular ions in a collision less rotating plasma were calculated for mass numbers: $\mathrm{UO}_{2}{ }^{+}$ions $(\mathrm{M}=270) ; \mathrm{Nd}_{2} \mathrm{O}_{3}{ }^{+}$ions $(\mathrm{M}=336)$; conventional ions of the multicomponent oxides $(\mathrm{M}=400)$. To allocate $\mathrm{UO}_{2}{ }^{+}$ions on a longitudinal collector, a radial electric field $E_{r}$ was set with the addition of a variable component

$$
E_{r}=E_{0}+k \cdot E_{0} \cdot \sin \left(\frac{\omega_{c i}}{2} \cdot t\right) .
$$

A variable component with an amplitude coefficient $k=0.6$ and $E_{0}=400 \mathrm{~V} / \mathrm{m}$ is tuned to a frequency equal to half the cyclotron frequency of $\omega_{c i}\left(\mathrm{UO}_{2}{ }^{+}\right)$, which allows one to separate $\mathrm{UO}_{2}^{+}$ions from molecular ions of lanthanides and other FPs that are deposited on the end collector.

The results of [6] indicate the advisability of using a plasma source (PS) with axial plasma injection. It should be noted that, in addition to uranium dioxide, in irradiated oxide fuel there is a number of various actinides and their oxides, from uranium-232 to curium oxides $(M=232 \ldots 277)$. In addition, during the conversion of SNF into plasma, both molecular and atomic ions of NF and FPs can be formed. Calculations showed that under the conditions specified above, at axial injection (Fig. 1), i.e. injection angle $\alpha=0^{\circ}$, singly charged atomic ions of actinides may not reach the longitudinal collector $(R=1.3 \mathrm{~m})$.

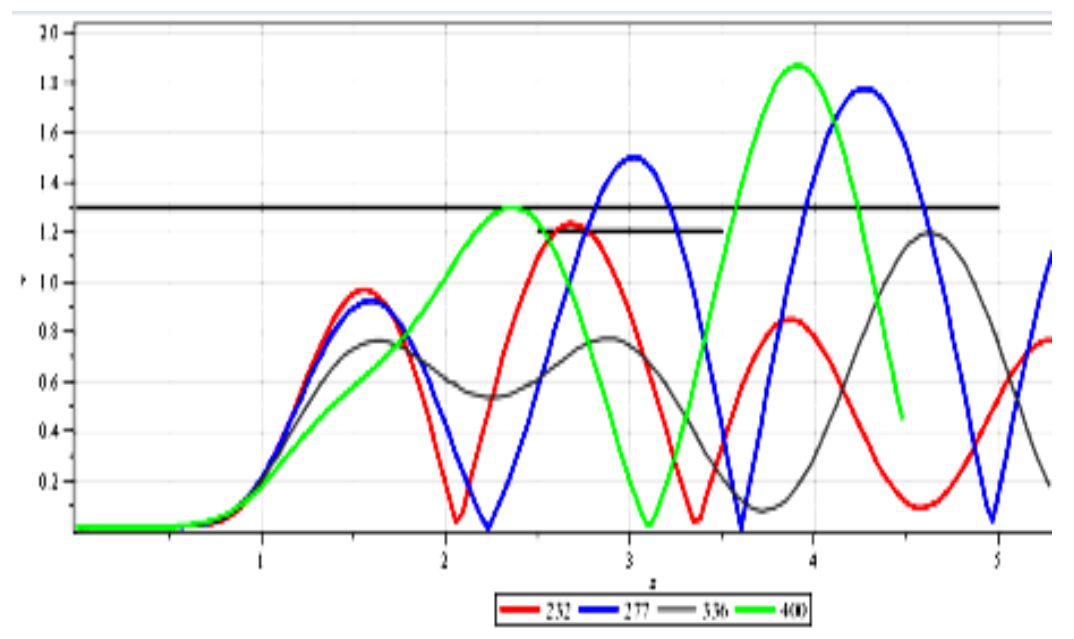

Fig. 1. Projections of the ion trajectories in $r \times z$ plane for $M=232 ; 277 ; 336 ; 400$

$$
(k=0.6 ; \alpha=0)
$$


It is possible to carry out the collection of atomic and molecular ions of actinides in a localized zone, in the so-called "pocket" (Fig. 2). In such a collector, target ions will be deposited on the inner surface of the "pocket"-collector.

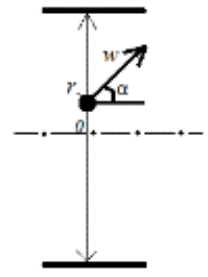

$a$

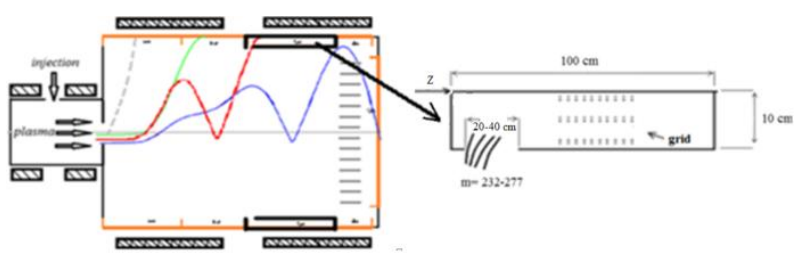

$b$

Fig. 2. Initial conditions ( $w$-energy, $\alpha$-angle, $r$-radius) of particle motion from the $P S(a)$; the actinide collection zone in the plasma mass filter ("pocket" profile) (b)

It is of interest to calculate the dimensions of the zone in which the target ions can be collected
$(M=232 \ldots 277)$. For this, it is necessary to set the parameters of the variable component of radial electric field (amplitude and frequency), which will ensure the entry of the target ions into the "pocket" of the plasma filter of masses.

\section{CALCULATION OF TRAJECTORIES FOR IONS OF A GIVEN RANGE OF MASSES IN THE PLASMA MASS FILTER AT VARIOUS INITIAL CONDITIONS}

The main components in the SNF plasma are atomic and molecular ions of uranium-238, therefore, to collect the target ions in the "pocket", it is advisable to determine the ion-cyclotron frequency for $\mathrm{M}=238$ in the separation area with a magnetic field of $0.1 \mathrm{~T}$.

The calculations showed that the variable component of the electric field, tuned to a frequency equal to half the ion-cyclotron frequency for $\mathrm{M}=238$, provides the entry of ions $(M=232 \ldots 277)$ into the collector ("pocket"). In order to reduce the probability of the target ions coming out from the annular hole of the "pocket", the amplitude coefficient for a variable component of radial electric field is enough to increase from $k=0.6$ to $k=0.7$ for the collision of ions with the inner wall of the "pocket". For these conditions, the minimum width of the inlet of the "pocket" is determined by the paths of the ions $\mathrm{M}=232$ and 277 (Fig. 3) and with respect to the length of the actinide collection zone is 0.2 , or $0.2 \mathrm{~m}$ in absolute units.

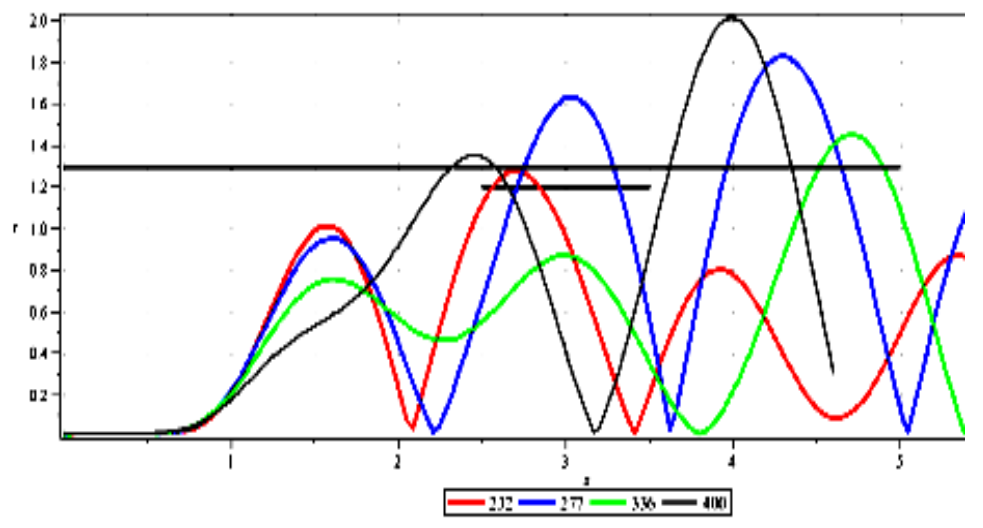

Fig. 3. Projections of the ion trajectories in $r \times z$ plane

$$
\begin{gathered}
\text { for } M=232 ; 277 ; 336 ; 400 \\
(k=0.7, \alpha=0)
\end{gathered}
$$

To determine the maximum width of the inlet, the influence of the initial conditions (energy, angle, radius) on the ion trajectory $(\mathrm{M}=232 ; 277 ; 336 ; 400)$ in the plasma filter of masses (Figs. 4-6) was studied.

An analysis of the results showed that a slight scatter in the initial parameters leads to an increase in the width of the inlet in factor of twice: from 0.2 to $0.4 \mathrm{~m}$ in absolute units. At the same time, the "pocket"-collector area is reduced by $1.5 \mathrm{~m}^{2}$, and the specific heat load increases by $\sim 10 \%$.

It follows that there are limitations on energy, angle, and radius related to the initial conditions for the ion motion, which must be taken into account when creating the plasma source for the plasma mass filter, which is currently being developed. 
Initial angle range, $\alpha\left(-15 \ldots+15^{\circ}\right)$

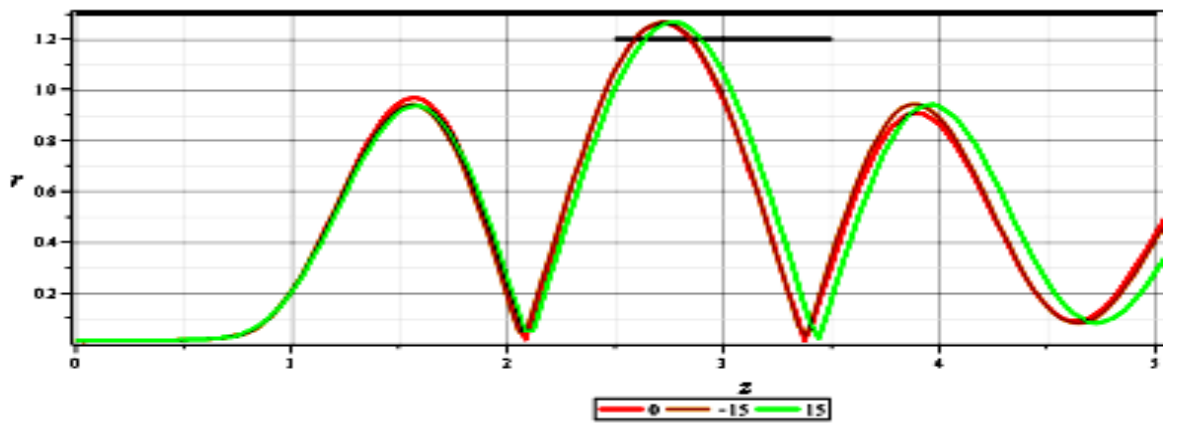

$\mathrm{M}=232$

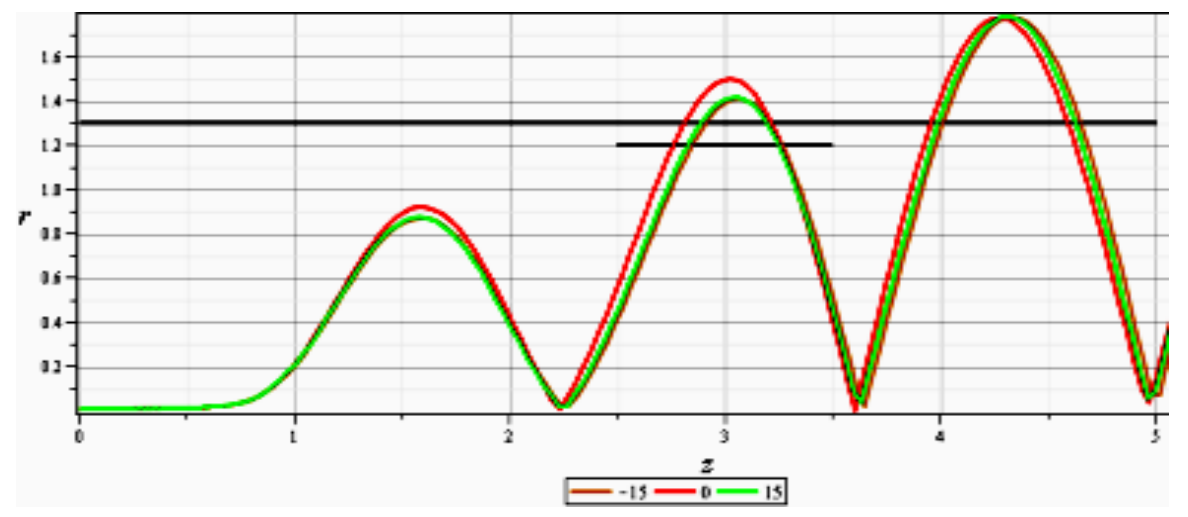

$M=277$

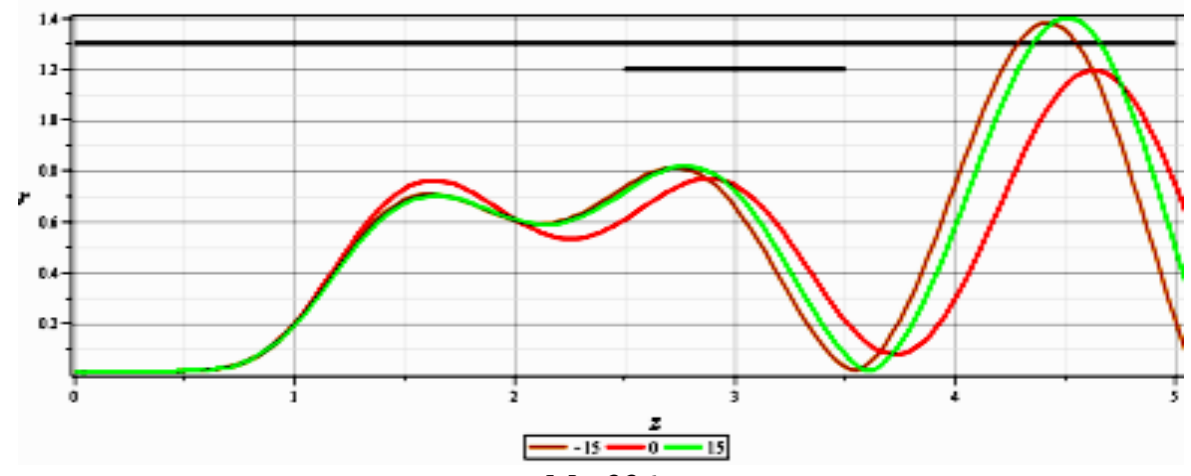

$M=336$

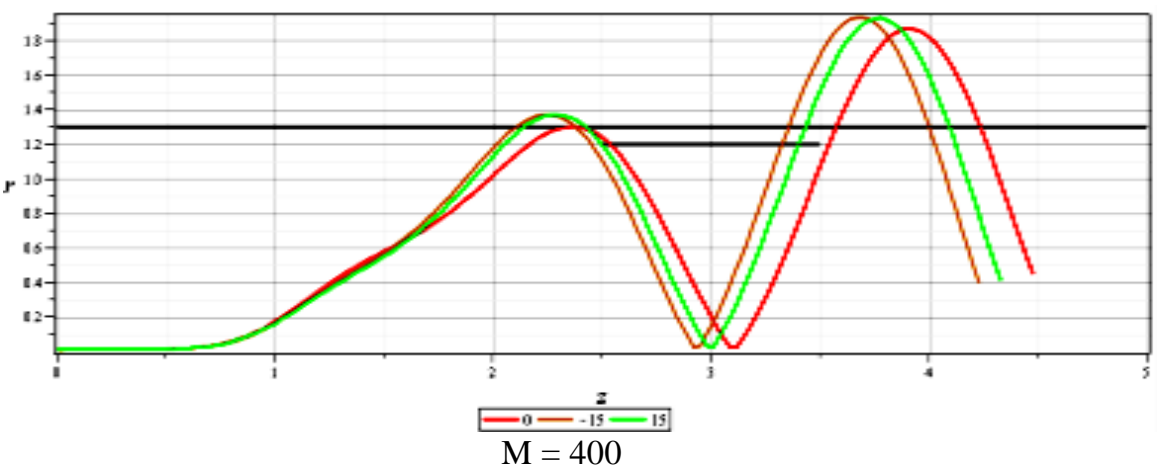

Fig. 4. Projections of the ion trajectories in $r \times z$ plane $(k=0.7)$ 
Initial energy range, $w(4 . . .6 \mathrm{eV})$

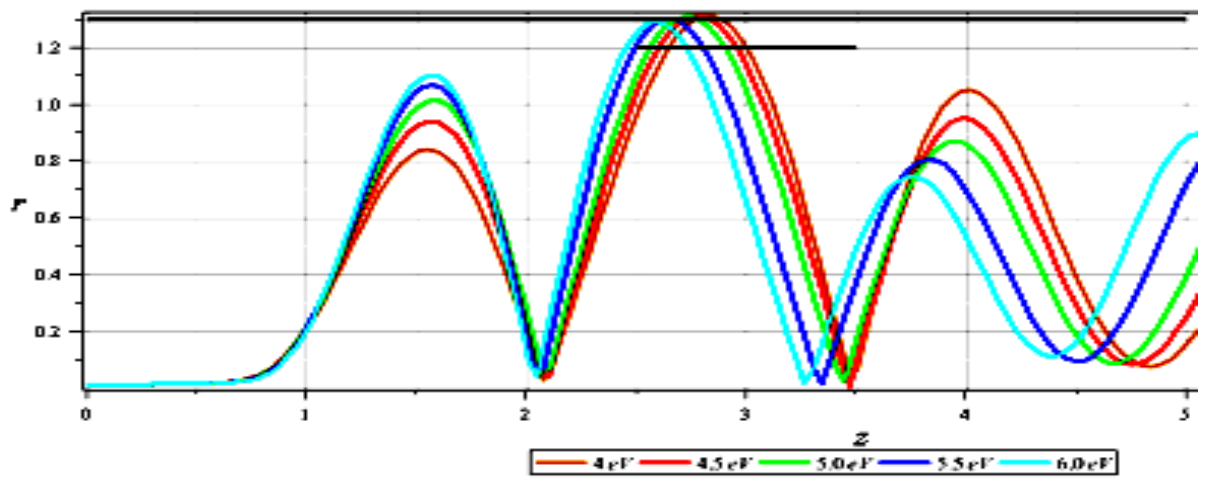

$$
M=232
$$
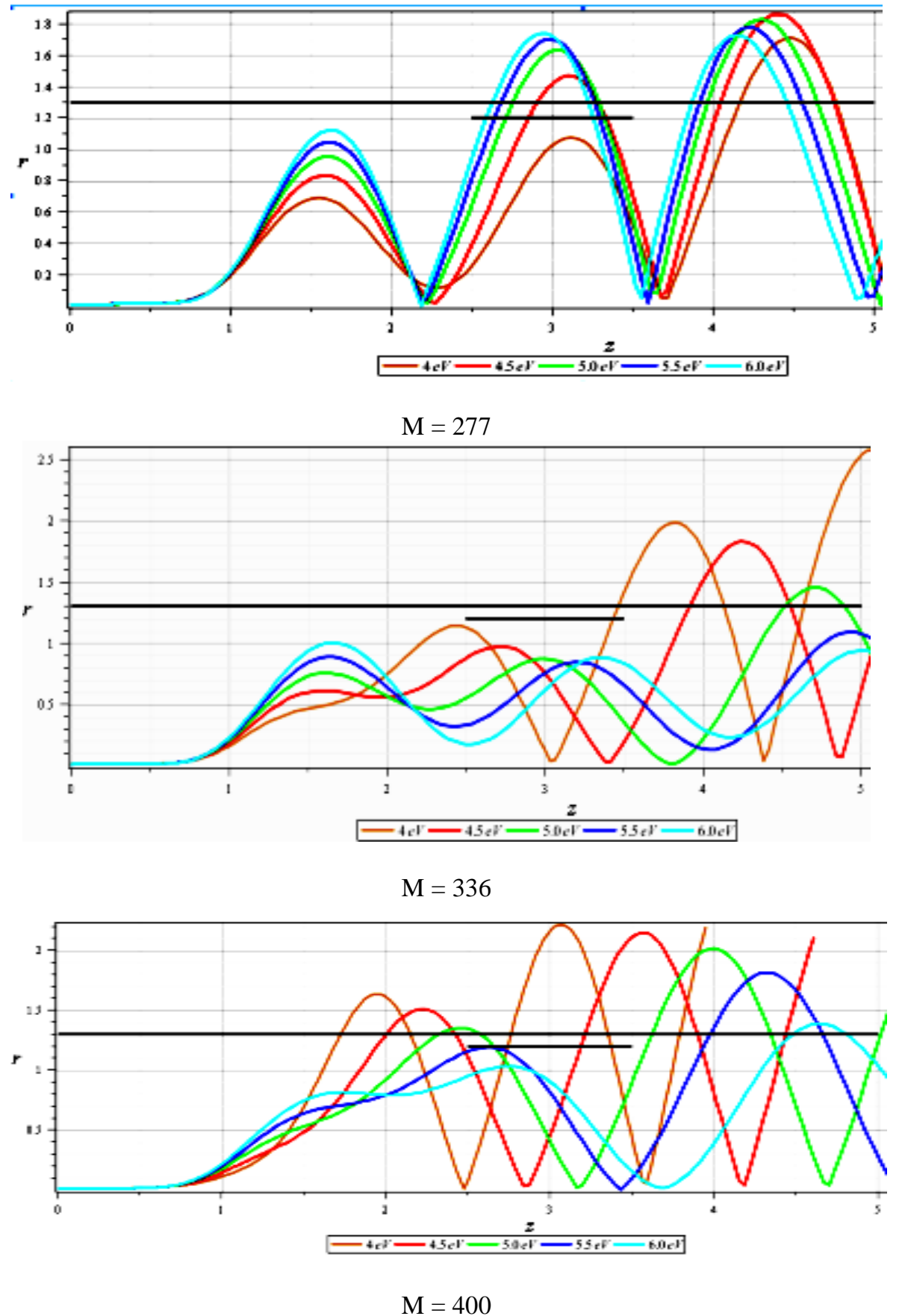

Fig. 5. Projections of the ion trajectories in $r \times z$ plane $(k=0.7 ; \alpha=0)$ 
Initial radius range, $r(0.01 \ldots 0.03 \mathrm{~m})$
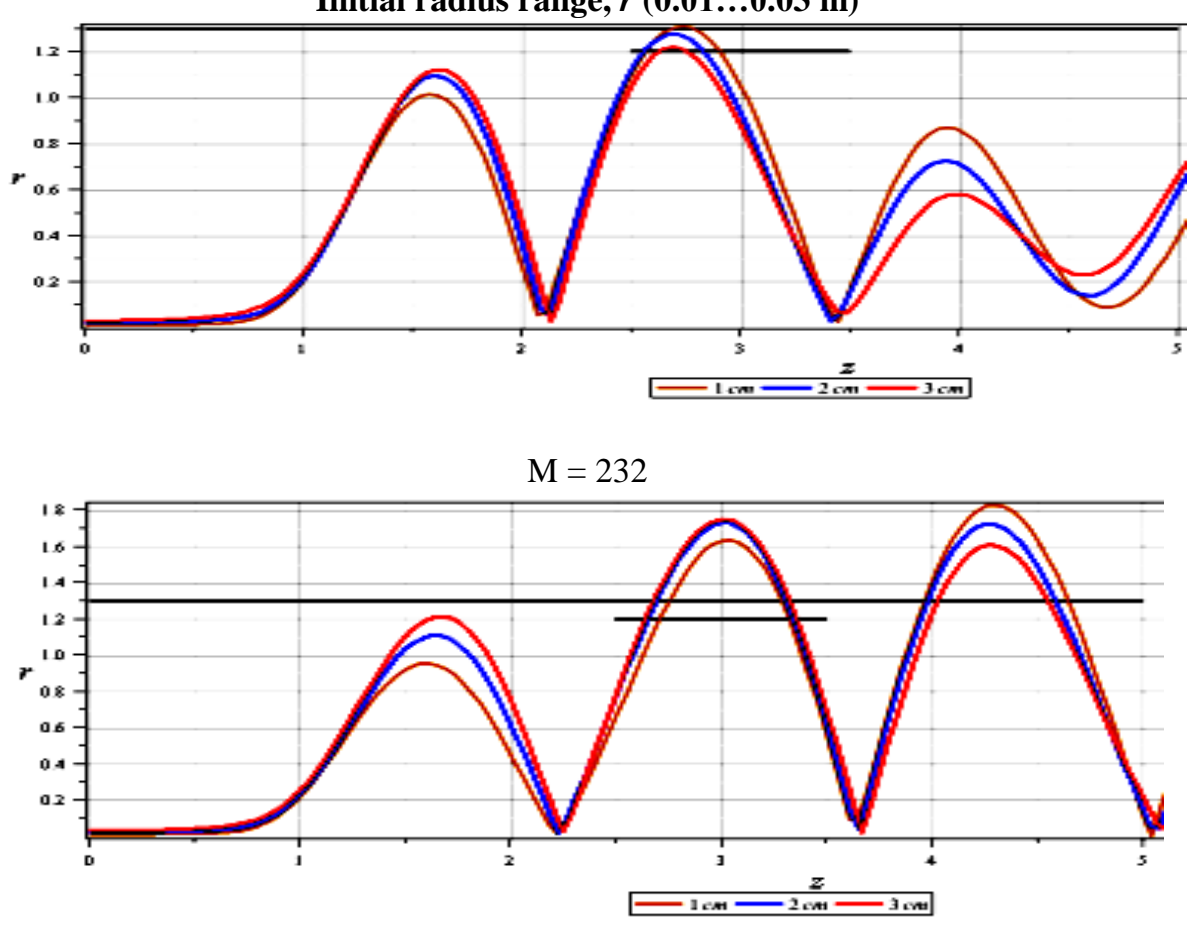

$\mathrm{M}=277$

Fig. 6. Projections of the ion trajectories in $r \times z$ plane

$$
(k=0.7 ; \alpha=0)
$$

\section{CONCLUSIONS}

The influence of scatter in the initial energy $w(4 \ldots 6 \mathrm{eV})$, the initial angle $\alpha\left(-30 \ldots+30^{\circ}\right)$ and the initial radius $r(0.01 \ldots 0.05 \mathrm{~m})$ on the trajectory of molecular and atomic ions of a given mass range to reach the collector ("pocket") in the plasma mass filter is considered.

For the ions of a given mass range $(M=232 \ldots 277)$ :

- The calculations showed that the variable component of the electric field, tuned to a frequency equal to half the ion cyclotron frequency for $\mathrm{M}=238$, with an amplitude coefficient $k=0.7$, ensures the entry of the target ions into the "pocket".

- The permissible scatter of the initial values (energy $w=5 \ldots 5.5 \mathrm{eV}, \quad$ angle $\quad \alpha=0 . .15^{\circ}, \quad$ radius $r=0.1 \ldots 0.02 \mathrm{~m}$ ) was determined, at which the target ions enter the "pocket".

- The width of the inlet annular hole for the target ions was determined, which is $0.2 \ldots 0.4 \mathrm{~m}$ at a length of the actinide collection zone of $1 \mathrm{~m}$ and a height of $0.1 \mathrm{~m}$. At the maximum width of the hole, the ion deposition area decreases by $1.5 \mathrm{~m}^{2}$ with an increase in specific thermal load on the ion deposition surface by $\sim 10 \%$.

Thus, the dimensions of the actinide collection zone in the plasma mass filter, which is currently being developed, are determined.

\section{REFERENCES}

1. S.J. Zweben, R. Gueroult, N.J. Fisch. Plasma mass separation // Physics of Plasmas. 2018, v. 25, p. 090901.

2. J.-M. Rax and R. Gueroult. Rotation and instabilities for isotope and mass separation // J. Plasma Phys. 2016, v. 82, 595820504, p. 1-15; doi:10.1017/S0022377816000878.

3. V.B. Yuferov, S.V. Katrechko, V.O. Ilichova, S.V. Shariy, A.S. Svichkar, M.O. Shvets, E.V. Mufel, A.G. Bobrov. Developing the Concept of Multi-Stage Spent Fuel Cleaning From Fission Products by Physical Methods // Problems of Atomic Science and Technology. Series "Vacuum, Pure Materials, Superconductors" (113). 2018, N 1, p. 118-126.

4. V.B. Yuferov, V.O. Ilichova, V.V. Katrechko, S.V. Shariy, A.S. Svichkar, M.O. Shvets, V.I. Tkachov, D.V. Vinnikov, A.N. Ozerov. The conceptual design of a demo-imitation separator - the model of a plasma mass filter for irradiated oxide uranium fuel // Problems of Atomic Science and Technology. Series "Plasma Physics" (118). 2018, N 6, p. 289-292.

5. Niko Kivel, Natalia Shcherbina, Ines GunterLeopold. Development of a high temperature treatement device for spent nuclear fuel // J. Radioanal Nucl. Chem. DOI 10.1007/s 10967-012-2046-X.

6. V.V. Katrechko, V.B. Yuferov, V.O. Ilichova, A.S. Svichkar, S.N. Khizhnyak. Influence of Initial Conditions on Separation of the Molecular Ions of Spent Fuel in the Plasma Mass Filter // Problems of Atomic Science and Technology. Series "Nuclear Physics Investigations” (115). 2018, N 3, p. 192-195.

Статья поступила в редакцию 09.10.2019 2. 


\title{
ЗОНА СБОРА ИОНОВ ЗАДАННОГО ДИАПАЗОНА МАСС В ПЛАЗМЕННОМ ФИЛЬТРЕ МАСС
}

\section{В.В. Катречко, В.Б. Юферов, В.О. Ильичева, А.С. Свичкарь, С.Н. Хижняк}

Проведены расчеты траекторий движения атомарных и молекулярных ионов заданного диапазона масс $(\mathrm{M}=232 \ldots 277)$ в плазменном фильтре масс, который разрабатывается в настоящее время. Исследовано влияние начальных условий (энергии, угла, радиуса) на траектории движения ионов для определения геометрических размеров зоны сбора актиноидов, так называемый «карман». Показано, что переменная компонента радиального электрического поля, настраиваемая на частоту, равную половине ионной циклотронной частоты для $\mathrm{M}=238$, обеспечивает вход целевых ионов в коллектор-«карман». Анализ расчетов показал, что существуют ограничения по энергии, углу и радиусу, связанные с начальными условиями движения ионов, что необходимо учесть при создании плазменного источника для плазменного фильтра масс.

\section{ЗОНА ЗБОРУ ІОНІВ ЗАДАНОГО ДІАПАЗОНУ МАС У ПЛАЗМОВОМУ ФІЛЬТРІ МАС}

\author{
В.В. Катречко, В.Б. Юферов, В.О. Ільічова, О.С. Свічкар, С.М. Хіжняк
}

Проведено розрахунки траєкторій руху атомарних і молекулярних іонів заданого діапазону мас $(\mathrm{M}=232 \ldots 277)$ у плазмовому фільтрі мас, який розробляється в даний час. Досліджено вплив початкових умов (енергії, кутку, радіусу) на траєкторії руху іонів для визначення геометричних розмірів зони збору актиноїдів, так званий «карман». Показано, що змінна компонента радіального електричного поля, що настроюється на частоту, рівну половині іонної циклотронної частоти для $\mathrm{M}=238$, забезпечує вхід цільових іонів у колектор-«карман». Аналіз розрахунків показав, що існують обмеження по енергії, кутку і радіусу, пов'язані з початковими умовами руху іонів, що необхідно врахувати при створенні плазмового джерела для плазмового фільтра мас. 